\title{
Violence or Emancipation?
}

\author{
Cándida Elizabeth Vivero Marín \\ Gender Studies Center, University of Guadalajara, Guadalajara, México \\ Email: elizabeth_vivero@hotmail.com
}

How to cite this paper: Marín, C.E.V. (2017) Violence or Emancipation? Open Journal of Social Sciences, 5, 13-28. https://doi.org/10.4236/jss.2017.59002

Received: June 30, 2017

Accepted: August 29, 2017

Published: September 1, 2017

Copyright $\odot 2017$ by author and Scientific Research Publishing Inc. This work is licensed under the Creative Commons Attribution International License (CC BY 4.0).

http://creativecommons.org/licenses/by/4.0/

\begin{abstract}
In the Mexican narrative written by young women, symbolic violence is present through an implied feminist emancipatory project. In the novels Señorita Vodka by Susana Iglesias, and Por el lado salvaje by Nadia Villafuerte, the hypersexualization of the female body restates prostitution as an inseparable activity of being-woman. So, the violence suffered by female characters is naturalized and they themselves accept subordination and subjugation. Both texts end up reinforcing the notion of the female body just for the enjoyment and service for the others, canceling a real possibility of release.
\end{abstract}

\section{Keywords}

Body, Sexuality, Emancipation

\section{Introduction}

Symbolic violence, as outlined by Pierre Bourdieu, is an implicit form of domination accepted by the dominated part, practically without hesitations. Through several mechanisms and institutions, symbolic violence determines power relations that are difficult to fight against, as it transforms inequalities into something "natural". By introducing feminine and masculine characters in gender roles and circumstances that perpetuate domination and subjugation of the female by the male, artistic discourse, specially literature, contributes to the institutionalization of violence against women.

In novels published by Mexican female writers who were born in the 1970s, violence against women is made present through the hypersexualization of the female bodies that end up engaging in prostitution as an inseparable activity of being-woman. The main characters of the novels Señorita Vodka by Susana Iglesias, and Por el ladosalvaje by Nadia Villafuerte are represented by the figures of an exotic dancer and a migrant, respectively, in an attempt of the writers to exhibit the emancipation degree achieved by women. Nonetheless, their approach 
still reproduces the violence from which these women suffer through domination and subordination relations as, in the end, they have accepted the patriarchal discourse that makes them inferior.

The aim of this paper is to analyze the way in which violence against women is naturalized through these two novels, using an emancipatory and libertarian speech that disguises the subjugated condition they suffer from as a result of their bodies being hypersexualized. The analysis of the novels will be carried out based on gender studies, Pierre Bourdieu's concept of symbolic violence, and some insights concerning porn and post porn. The paper is divided in three parts and a conclusion: the first part has to do with the context of Mexican female writers, the second part is about hipersexualization of the female body and the third part is about prostitution and post porn project in two novels written by two young Mexican female writers.

\section{Mexican Female Writers Born in the 1970s}

Mexican literary history and criticism has begun incorporating, studying, and analyzing male and female writers born after 1960 . This is a highly significant fact as, in studies like La literaturamexicana del siglo $X X$ [ The Mexican literature of the 20th Century], coordinated by Manuel Fernández Perea (2008) [1], or Literaturamexicana del siglo XX. Estudios $y$ apuntes. [Mexican literature of the 20 th Century. Studies and Notes] by León Guillermo Gutiérrez (2012) [2], the referred authors' publications were made by the end of the 20th Century. This coincides with the statement made by José Juan Arrom (1963) [3] about the periodization of Latin American literature, specifically regarding the fact that these authors' predominant period was thirty years after they were born. Therefore, new generations emerge every thirty years, instead of every fifteen years, as stated by Pedro Salinas (1970) [4]. So, if we are to consider Arrom's division, the predominant period of the authors born between 1954 and 1984 would be between 1984 and the current year (2014). Thus, the fact that the aforementioned Mexican-literature texts remain outside of the critical study is not strange, as the authors born in the second half of the 20th Century are at their heyday.

However, if we take the generational division recently developed by authors and literary critics like Ignacio Padilla [5], Tryno Maldonado [6], Alberto Chimal [7], Gabriela Valenzuela Navarrete [8], Emily Hind [9] [10], and Ramón Alvarado [11], the most recent Mexican authors have been grouped by decades. This means that, after the Generation of the 1950s-which was formed by the writers who were born between 1920 and 1935-the Mexican authors were no longer grouped by the aesthetic and ideological stand they shared (this was also the case of the so-called Boom), but by their dates of birth, specially by the decade in which their birth took place. So, according to what Salinas states, what strictly defines literary generations is not only the proximity of the date of birth, but also the aesthetic or structural affinities the authors have, along with a shared generational experience (cf. 1970). In spite of this, it is not only difficult, 
but also practically impossible to group the authors born in the 1950s under such premise, not to mention those born in the 1960s, as, in fact, there is no "similar way to perceive and reproduce the world, that of common ideas and postures, of shared interests and desires" (Pereira, as cited in Sáenz Valadez, 2011: p. 50) [12]. As a result, the way in which the current scholars and critics refer to the recent Mexican authors is by decades. Therefore, we are able to distinguish the authors born in the 1950s, 1960s, 1960s, 1980s and, lately, in the 1990s.

Thus, I will refer to the Mexican female writers born in the 1970s on the premise that there is no referent to make them hegemonic or that makes them converge in an aesthetic-literary proposal (cf. Domenella, 2001) [13]. Instead, there is an epochal spirit that penetrates their writing interests. Such interests are reflected both in the topics they tackle and in the use of certain narrators, along with the psychological configuration of their characters. When mentioning the Mexican female writers, José Carlos Castañeda-coincidently with what Carlos Fuentes pointed out in regards to this "generation"- summarizes to a large extent the distinctions of this group of writers: "rather than being a feminine literature, the women's prose is an individual type of writing, and its perspective does not depend on any collective order. By the contrary, it depends on the personality that each of them grants to her books" (2008: p. 489) [14]. This feature that Castañeda links to the authors is, as a matter of fact, extended to the whole set born as of 1960, and, as Alberto Chimal states:

People of such generation was said not to have a common proposal. The texts they have published do not share any sort of Poetics. In the end, they are all disperse: fragmented when, supposedly, authors of other generations would have written on a more systematic way, which would have been better. The idea had already been used in the prologue of the anthology Dispersiónmultitudinaria ["Multitudinous dispersion"], compiled by Roberto Max and Leonardo de Jandra, published in 1997, to talk about authors that were slightly older (born in the second half of the 1960s). Ten years after, the image of the disperse generation was repeated in many occasions, and it became popular. (2012: pp. 13-14)

In such context, it is not surprising that the female writers are effectively not continents, but islands that conform an archipelago. ${ }^{2}$ Certainly, as I already mentioned, such islands are connected by certain topics. However, each of them commits to its individuality and singularity. It is also true that all of them dialogue in specific moments, but each of them adopts a different stand towards the text and, in the specific case before us, towards the approach to violence against women. It should be noted here that, except for a few female writers, none of

\footnotetext{
${ }^{1}$ Translator's Note: All the translations of citations by Susana I. Sevilla-Beltrán, unless otherwise noted.

${ }^{2}$ In this part I take up the image used by Carlos Fuentes in respect of the writers of this generations [15].
} 
them undertake a feminist stand as, generally speaking, they consider literary writing as not being a subject matter pertaining to men or women, but a matter of simple aesthetics, even when this branch of philosophy-like all disciplines-has been built from a male-oriented viewpoint. Nonetheless, in spite of such non-recognition nor feminist assumption, the authors clearly know that, presently, women have been able to undergo specific experiences that were denied to their predecessors. Therefore, unlike female writers like Rosario Castellanos, Inés Arredondo, Guadalupe Dueñas, Elena Garro, or Amparo Dávila, the female authors born after 1970 have stopped worrying about denouncing or making evident the disadvantageous situation women live before men. They have made way to possible worlds were female characters are assumed as subjects of verbalization, capable of acting. On this grounds, the female characters in their texts are introduced as active subjects performing in different professions and trades, empowered, with a higher level of studies and, in most cases, single, divorced, or unabashedly enjoying their sexuality, without the mediation of marriage or parental responsibilities.

These features through which female characters are outlined speak of a generational change, while the female authors themselves have been able to enjoy the benefits achieved by their mothers and grandmothers. Despite this new dynamic of relating to the surroundings, the stories and novels of this group of female authors calls attention to the way in which the body, and hence sexuality, are assumed. Even when the female characters are autonomous in regards of enjoying their sexuality, in the end, the pretended emancipation is not achieved, as it continues to link their being-woman to their being-a-body-for-others. More specifically, the novels Señorita Vodka, by Susana Iglesias, and Por el ladosalvaje, by Nadia Villafuerte, seem to trace back the female condition-amidst a pretended emancipation - to the heteropatriarchal principle of woman-body, perpetuating the gender roles. As a result, both texts use literature as a symbolic violence mechanism.

\section{Hypersexualization of the Female Body: Release or Subjugation?}

Symbolic violence, as outlined by Pierre Bourdieu, is: "tout pouvoir qui parvient à imposer des signification et à les imposer commelégitimes en dissimulant les rapports de force qui sont au fondement de saforcê" [any type of power that allows the imposition of significance, considering it legitimate, and concealing the power relationships that are the foundation of the dominated part] (1972: p. 18) [16]. In this sense, René Barbierpoints out it is a matter of "violence", because there is an imposition, a power exercised over the recipient. It is a "symbolic" violence because it is significance that is imposed, as well as significance relations. It is "arbitrary", therefore, it contributes to the reinforcement of cultural and social inequality among classes, favoring certain classes to the detriment of others. Symbolic violence is thus considered as "culturally legitimate", as it appears as a 
"natural" exclusion and, for that matter, with a universally recognized value ( $c f$. Barbier, virtual publication) [17].

On his part, César Jerónimo Hernández Moralesasserts:

Symbolic violence, like everything that is symbolic in the self, is everywhere in the social sphere. Both those who are totally excluded, and those who want to compete for the well-being of a specific field are bound to recognize that the dominant's resources are the ones that are accepted, inasmuch as a field can only function if there are individuals socially-biased in favor of behaving as responsible agents. It is to say, agents who fight for winning and achieving the benefits this field proposes to them. For countless reasons, when there are biased individuals, reproduction and domination are always guaranteed. This is the way in which social aspects are reproduced and it is also the reason why, apart from ideological positions, social transformation is so complex. Especially when the revolutionary, almost eschatological epistemology of the proposal, is far from the symbolic problems. The power given to the dominant constitutes the basis of symbolic violence, leading the dominated to exercise the domination relations upon themselves, and what ensures their existence is the fact that they ignore them as such. (virtual publication, pp. 3-4) [18]

In this scenario where power relations are supported by the symbolic aspect, literature plays a fundamental role in stereotype perpetuation and, mainly, in the subjugation of women to certain practices, while subordination is represented as "natural". For this reason, according to María Socorro Tabuenca Córdoba, narrative-particularly novel-is considered as an artefact to "internalize social standards, even when they also provide social criticism” (2004: p. 202) [19]. By making evident the world's vacuum, the dilemma of the oppressed or our most noble aspirations' failure, novel invites the female readers to feel identified with the circumstances presented and to consider them as intolerable ( $c f$. Tabuenca Córdoba, 2004: p. 202). However, in spite of this noble awareness function, literature may be used as a mediudm to retransmit these social standards.

Both Ángeles de la Concha (2012) [20], and Natasha Walter (2010) [21] underpinin their respective studies that literature-mainly prostitutes diariescreate an imaginary around female hypersexualization by creating "libertarian" images that, far from effectively emancipating women from their generical-sex condition, restricts them even more under their plain function as sexual objects. Although de la Concha asserts that: "The appearance of the second stage of feminism in North America in the seventies made it possible firstly, to challenge, and secondly, to break this naturalization, which allowed the rise of a strong reaction towards the stratification of the sublimated representations of gender violence to which [...] the canon had us accustomed to" (pp. 143-144), such process has not only being mired in its project towards the emancipation and release of female sexuality, but has transformed, almost at the end of the first two decades of the $21^{\text {st }}$ Century, in more of a sort of prison. According with Walter, 
this symbolic violence exerted from different environments through multiple cultural products like prostitutes' memoirs has not triggered the dreamed, projected and expected release that feminism of the seventies or eighties wanted. On the contrary, such literature-along with several products tied to the sex industry (like men's magazines, fashion, plastic surgery, among others) - seem to prevent women from openly manifesting their desires by imposing a model upon them to act and sexually conduct themselves in a way that is more promiscuous and rampant than uninhibited (p. 41 and ff.).

In this context, literature (like videogames, films, lyrics, etc.) plays a key role when building an imaginary around the affective and emotional socialization of the individuals (women and men). When referring to a study carried out by Dietz regarding videogames, Esther Oliver and Rosa Valls outline: "videogames keep using the same old topics regarding women: they have to be victims and people in need, they must be beautiful and remain sexually attractive. Boys should be protective, defend women and attain them, even through the use of violence" (2004: p. 100) [22]. This dilemma that was apparently overcome by whores' writings (dilemma that will be referred to further on in the text) is not completely different; according to Walter, in the literature written by womenspecifically in the narrative of Mexican young female writers-it is clearly observed how such "subversion" of the gender stereotype (woman-victim-in need of help and protection) does not really break the naturalization of women's bodies, placing them, again, as sexual objects. Presumed release, achieved even through strategies that are equally violent to those used by the masculine counterparts (like in the case of the novel Perra Brava of another Mexican female writer, OrfaAlarcón), do nothing but evidence Walter's refined observation on the current and widespread prostitutes' memoirs, namely: "These prostitutes diaries that have become fashionable narrate a lifestyle that their readers want to consider as different from such type of violence [physical and sexual, that may lead to death of the prostitute herself]." (p. 36)

It is true that, as aforementioned, in the particular case of the Mexican female authors born after 1970 there is no position that could openly respond to the heteropatriarchal hegemony and binarism. So, first of all, it would not be legitimate to request or demand for their texts to reflect the presence of something that, de facto, is not intended to be formulated. However, it is feasible to analyze and make a critical reading on the way in which the authors assume emancipation or women's release through representation.

In this way, in the novels Por el ladosalvaje and Señorita Vodka, we immediately find two female characters that make their way through decadent worlds. In the first case, Líastarts describing her current situation where her body is used only for the enjoyment and satisfaction of her lover; in the second, there is a second description of the almost eschatological situation in which Señorita Vodka lives, as she is always facing death. Below, the beginning of both novels:

Sex is all that keeps me attached to life. I knew this from childhood. And I 
had no childhood. That land of which everyone speaks was inexistent to me. There are no pictures, that is what I mean. (Villafuerte, 2011: p. 13)

[23]

My days of misery began the night I held a gun in my hands. You wouldn't be able to imagine it neither if you look at me, nor if you talk to me. No one can open the heart of a person that does not exist. I am a woman who built her life amidst a weak tower of mired heartbreaks and desire. (Iglesias, 2013: p. 9) [24]

If we observe the syntagms "Sex is all that keeps me attached to life" and "My days of misery began the night I held a gun in my hands", we can observe the sex-violence relation set out from the beginning as, in both cases, the lives of the main characters are tied to those elements "that keeps me attached to life", "my days of misery began". The main purpose of the narration, therefore, is revealed to us from the beginning of the novels, purpose that will continue to be developed as the stories move forward. It is also to be highlighted that the texts start in media res so that, further on in the text, there is a way to recount-through a series of analepsis and prolepsis-the preceding facts that led to their current situation and projected the events towards the endings that, at first sight, would seem releasing. Narrative tension or suspense, as MiekeBal (2006) [25] indicates, is then achieved due to the questions the reader makes him/herself with regards to examples such as: Why weren't there any childhood pictures? or Why would the main character say she does not exist? When capturing the reader's interest, the narrators-main characters start to reconstruct their stories that, stepwise, are seen to be framed by highly-violent environments, both at physical and psychological levels.

Consequently, it is no wonder that in the development of the stories, the life conditions suffered by the main characters are referred to from time to time. Few paragraphs ahead, Lía states: "But he teaches me well in grounds of submission and fear and, while I'm reluctant in the beginning, sometimes, as a result of such quiet haughtiness, I blame myself [...]" (Villafuerte, 2011: pp. 13-14). Meanwhile, Señorita Vodka adds: "sleet mixed with ice-cold vodka, pain, betrayals, bullets. The Russian roulette was my favorite game [...]" (Iglesias, 2013: p. 9). The emphasis and reiteration on violence reinforce the aggressive environment that surrounds them. As already outlined in multiple occasions, the most evident form of violence is physical, although apart from psychic and sexual violence, other forms of violence like economic, affective, emotional and patrimonial also exist, all of them resulting from structural and cultural violence. ${ }^{3}$ In the middle of the violence cycle they suffer from, the appropriation of the main characters' bodies by the masculine characters correspond to what is considered as "natural" in intergeneric relations: men, as physically-superior beings, may subjugate women and satisfy their sexual desires over the use of force. Hence,

${ }^{3}$ For further information on the types of violence, refer to: Diana Valle Ferrer (2011) [26]; Eva Espinar Ruiz y Miguel Ángel Mateo Pérez (2007) [27]. 
the main characters shall be subordinated to the orders of their masculine counterparts.

That said, throughout the stories, the main characters become conscious of their subordinated condition and they subvert it. Notably, Señorita Vodka assumes herself fully as a hypersexualized body and takes up this condition as a means of empowerment. ${ }^{4}$ At first, it is her who decides to engage in prostitution, even offering her services through a newspaper's advertisement:

As a friendly misanthropist, I wrote in that ad: FRIENDLY MISANTHROPIST WITH ENORMOUS HIPS SEARCHING FOR A SIMPLE, WELLPAID JOB. ASSHOLES, JOKERS AND LIARS, REFRAIN FROM CALLING. Many replied to my ad, but just one fulfilled my requirements: Report yourself with working clothes at six o' clock in Eje Central Avenueon the corner of República del Salvadorstreet. I arrived on time. My date recognized me because of my gorgeous high heels. Then, we walked to the workplace. Empty second-class whorehouse. Two clients only. That's how my first day was like [...]. (Iglesias, 2013: p. 11)

In contrast, Lía, Por el ladosalvaje's character, enters the prostitution world when she is sold by a friend of her guardian. Lía, who illegally crosses the border to Honduras, suffers from psychological and sexual violence from the man who takes her with him to that country. In her effort of turning away from this form of life, she relies on a friend of this man who, after a series of obscure agreements with a sex slaver, finally sends her to Tijuana with a special shipment: Lia's mission is to contact a photograph buyer to whom she has to deliver the photo negatives found by her guardian's friend. Lía is unaware of the fact that, while she waits for such encounter, she will have to engage in prostitution to "pretend" she has a "profession", not to raise espionage suspicions:

Draco $[\ldots]$. He says that he makes transactions with people from the customs office who operate in the clandestine border-crossing. A minor figure, a point man. His best business is at the warehouse: the Lonely. [...] Only after will I learn that this is a smoke curtain. The truth is that, inside, women trafficking is practiced. Young women. Mostly Central Americans: foreign jogging for the locals. Draco belongs to some sort of organization that transfers them from their places of origin: the exchange of fresh flesh, diseased flesh, girls who share their make-up, foreigners recognizing themselves through friendship. (Villafuerte, 2011: p. 166)

Hence, both of them accept their situation by their own or someone else's

${ }^{4}$ Hypersexualization refers to the representation of the child as some sort of mini sexual adult. This term was coined by the Canadian sexologist Jocelyne Robert (in Roca, 2013) [28], who points out that in occidental societies, during the last years, an eroticization of postures, clothing, and expressions has been produced. In my argumentation I transfer this term towards the aggravation of the eroticized female body that is extremely commodified by prostitution and the pornographic industry, which have been responsible of the over exposition of the woman's body as a body that is at service for the enjoyment and satisfaction of others. 
decision, as something natural of being-woman. It is to say, both of them see in prostitution a sort of destiny they cannot escape from as, in the end, they are women. The hypersexualization they face is not called into question by them, and even less by those who are witness of it as, in both environments, they are expected to tolerate and withstand sublimage. It is true that Señorita Vodka takes ownership of this heteropatriarchal conception in an attempt to subvert and transgress the sexual interdiction imposed over women that are deemed decent. Thereof, Señorita Vodka pretends to subvert the order by being herself who seeks after her own release, using the same vision that revolves around woman. However, both Señorita Vodka and Lía-who in the end also takes ownership of her sexuality and constantly uses it as a bargaining chip for her benefit and to escape slavery-do not achieve their aim of release, as they get caught by an emotional and affective dependency either towards her former partner (in the case of Señorita Vodka) or towards a violent world marked by the dominance and giddiness male-oriented values (in the case of Lía):

Time is over. I don't need planting any more thoughts into my head. I don't want to plant more thoughts. To climb the stairs of the old building, to open the door to my apartment, to take out the box with six bullets, to put them in the revolver, to delete the files of the new computer, to caress my bed, to look at your picture, to hold tight that little quartz crystal whale you gave me. To run up the stairs to the rooftop [...]. (Iglesias, 2013: p. 212) I get used to harsh words. "What you love, you will lose" I was once told by the wise Margit. When others repeat those words, I'm ready to receive them: I domesticate their fierceness, I get used to their violent friction, I even seek after them.

[...] Her anxiety is absolute: she sees it all and understands nothing but, in that specific moment, she does not care. There are no shadows in the sky: just speed. (Villafuerte, 2011: p. 402)

\section{Prostitution and Post Porn Project or the Strengthening of the Woman-Body}

Expanding on the previous idea, if we do it on the basis of the post porn project that, in a synthetic way, seeks the vindication of sexual practices that are different from those designated by heteronormativity, it is possible to read the acts and conducts of the main characters as releasing. In such a sense, post porn research takes ownership of the term "pornography" (composed from the Greek terms "porné" and "graphos"), which refers to the "writing of the whore" (Echevarren, 2009: p. 7) [29]. So, pornographic stories:

[...] are sustained by the alleged confessions of a whore, one who enjoys her profession and is capable of enjoying with her clients. The discourse of the whore is the setting of a framework of stories intended to arouse the reader, to make him have a good time with episodes of erotic encounters in his autonomous field of pleasure, away from the concerns or hardships of real 
prostitutes. The enjoyment of the prostitute is hypothetical [...]. (Echevarren, 2009: p. 7)

Therefore, according to Roberto Echevarren, in all erotic representations there is an underlying "fantasy of domination" or "fantasy of acceptance". In the first concept, the pleasure of the subjected has no importance, whatsoever. In the second, the superior part "assumes, imagines or has the experience of the enjoyment of the inferior part and ascribes it to the whore" (2009, p. 7). In both cases, from the viewpoint of mandatory heterosexuality, the woman will be the one to assume the role as dominated before the dominator man, strengthening the gender roles and the passive/active dichotomy.

However, in the post porn project, such positions are infringed as, in the end, there is an intent of subverting the sexual stereotypes and of vindicating the dissenting sexualities. As a result, post porn is synthetized in the formula: "flesh + politics" (Echevarren, 2009: p. 68). This political dimension of erotica is what leads María Llopisto establish that post porn

takes the pornographic device like a cross-linking place of three political and cultural criticism spaces that are, at the same time, connected and discontinuous: feminism, as a language and practice of expanding the horizon of the public sphere by criticizing gender oppression; the queer movement of dissident sexual minorities, which criticizes the heterosexual standardization; the punk, as a practice for the invention of new inexpensive techniques of critical intervention (do it yourself, become the media), calling upon its improper, filthy and irretrievable dimension. (Llopis, as cited in Echevarren, 2009: pp. 69-70)

In such a way, the post porn project is not after the inversion of roles (from masculine to feminine and vice versa). Instead, it attempts to dissolve the binary division and to establish a gender that is "fluent, ambiguous, and astute" (Echevarren, 2009: p. 72). So, for example, in the particular case of sexual violence, Marie-Hélène Bourcier (2011) [30] states that it (sexual violence)is reserved for the male action. Therefore, if a woman demonstrates violence or expresses violent features, she is not a woman (cf. 2011: p. 14). When she refers to what she considers the first French post porn movie, Baise-moi, Bourcier asserts that the violence women exercise against male bodies breaks the heterosexually-correct standards and impose over women a submissive way of behaving when it comes to sexual intercourse:

Mais qu'elle soit lesbienne ou non, la femme butch est menaçante parce qu'elle renvoie en miroir une forme de violence don't les hommes sont habituellement les sujets et non les objets. C'estl'une des clés pour comprendre certaines réactions masculinistes déclenchées par Baise-moi. [Being lesbian or not, the butch femme is menacing, as she reflects a form of violence of which men are usually the subject, not the object. This is one of the keys to understanding some chauvinist reactions unleashed by Baise- 
moi]. (2011: p. 14)

Even when, as previously highlighted, post porn is not limited to the inversion of gender roles, but to proposing a "democracy for the bodies" ( $c f$. Echevarren, 2009, p. 73), the fact is that movies like Baise-moi attracted attention, first of all, as a result of their renegade disposition towards the pornographic imaginary. Currently, film projects like the ones of Erika Lust [31] or Diana Torres' performances [32] strive to disturb that submission-domination dynamic, so that pleasure and roles exchange are enjoyed in the same way by women and men. Thus, post porn is strongly associated to queer and transfeminism (the latter, for its part, linked to the de-colonial theory). ${ }^{5}$

For all of the above, the post porn project lays within a trend of emancipation of desire and reshaping the body either of a woman, man, non-woman, non-man, among others. But, is this purpose accomplished in the particular case of Por el ladosalvaje and Señorita Vodka? Firstly, it is to be highlighted that these novels are not considered as explicitly pornographic even when, in both of them, a high degree of sexual violence is represented and some sexual aspects are expressed unreservedly. Such violence linked to sex or, more specifically, to sexual practices, is not made evident as to consider the texts pornographic, even when it is the "writing of whores". Secondly, as the novels are not openly allocated in pornographic grounds, it cannot be said they allude to a post pornographic project. Albeit of these two insights, the two texts in the scope of this research pretend to establish the free practice of sexuality as a project that emancipates or releases the main characters.

As discussed above, in the end, the two main characters concur in a blameless assumption-desire-wise-of practicing their sexuality and, as a result, they are the ones to recount their sexual experiences. Moreover, they are the ones to foster the encounters with different men who, sometimes, are not charged for the service. As set out by Walter's research, such dissociation between the affective and emotional sides and the practice of sexuality with no inhibitions is one of the most striking features of this type of literature, while the main characters are assumed as objects without affection. In the novels here studied, the additional fact of the characters' decision at some point of not charging for their services provides them with an alleged moral superiority with respect to their clients, as they place themselves beyond economic necessity. Nonetheless, as Walter highlights, none of these postures reduces (not to say abolishes) the image that is kept of prostitutes: "women whose sole purpose is to sexually satisfy men" (2010, p. 37). This dissociation between body and feelings, where the life of the prostitute is conceived to have more nuances than the life of other women, may be

\footnotetext{
${ }^{5} \mathrm{As}$ to the relation between post porn and queer, refer to the paragraph "Cecinést pas une pipe: BurceLaBrucepornoqueer" in Marie-Hélène Bourcier (2011, pp. 32-49). As to the relation queer-transfeminism, refer to Sayak Valencia’s article, "Teoríatransfeministapara el análisis de la violenciamachista y la reconstrucción no-violenta del tejido social en el México contemporáneo" [“Transfeminist theory for analyzing the chauvinist violence and the non-violent reconstruction of the social fabric in Contemporary Mexico"], in Universitas Humanísticas (2014) [33].
} 
observed in the following citations:

I did not want to stop it. My body answered to that impulse, my body remembered something. He started touching me. I took his shirt off and started caressing his ass. He dipped his hands under my dress [...]. At some point, we were naked in that kitchen. He placed me on the kitchen bar. $\mathrm{He}$ ran his tongue all over my genitals, licking, twisting, fiddling around with those smooth, well-groomed fingers. (Iglesias, 2013: pp. 126-127)

My job is simple: there's a whole on the cabin's wall and, from there, I jack men off or I suck as efficiently as a milker would do [...].

There are boring jobs. I have already said mine is not of that kind. Mine is not an ordinary life and it seems to be clear now. But no life is, until someone else comes and watches it from the outside, which implies only looking at a portion of it. (Villafuerte, 2011: pp. 172, 173)

The enjoyment and ownership of sexuality achieved by the two main characters suggest a feminist project based, precisely, in the free practice of prostitution. In Lía's particular case in Por el ladosalvaje, resignation seems to be the first step towards that sexual empowerment amidst a series of violent and discriminatory practices, result of her disabled condition (Lía lacks a part of her arm, due to malformation).

Nevertheless, in spite of this proposal of feminine emancipation through the conscious and consented practice of sexuality, both characters do not perceive different forms to develop their affective or intellectual capacities as, in the end, they both think that, as a result of being women, they are ineluctably linked to their woman-body condition and, therefore, to being body-for-the-enjoymentof-others. Since she cannot possibly build a life project as an independent and autonomous woman, and before her lack of emotional abilities to establish healthy affective relations, Señorita Vodka decides to play one last time the Russian roulette, but this time with six bullets. Meanwhile and all of a sudden, Líafinds herselfto be free, alone, without menafter a police raid that, strangely enough, did not take place at the brothel, but during a public demonstration where she and her procurer got trapped. For this reason, after a series of unforeseen circumstances, Lía is thrown to the streets without any money, but bedazzled by an absolute freedom that was unknown to her:

Time is over. I don't need planting any more thoughts into my head. I don't want to plant more thoughts. To climb the stairs of the old building, to open the door to my apartment, to take out the box with six bullets, to put them in the revolver, to delete the files of the new computer, to caress my bed, to look at your picture, to hold tight that little quartz crystal whale you gave me. To run up the stairs to the rooftop [...]. (Iglesias, 2013: p. 212) Sometimes, the beginning of a person is delayed. An absent life or a non-existence can last a long time. Is it an abnormality? Maybe it is the fact that images are missing. My image(s) start here, when I am stranded, moneyless, 
without persecution, without men. Even my body functions threaten not to respond anymore. (Villafuerte, 2011: p. 400)

So, in both novels, hypersexualization of the female body, the ownership of violent conducts, (Señorita Vodka) and the assumption of the main characters as women-body, lead both to an extreme situation that places them before a crossroads whether to continue or end with their existence. Thereupon, in spite of the great emphasis they place on sexuality, these stories conclude with the commitment towards women release, through other ways that are unknown, but can be guessed. That is, in the end the main characters experience the awakening of consciousness that makes them glimpse other possibilities for them, even when they do not know what those possibilities are and how to achieve a genuine empowerment. They both sense they are more than a sexualized body but, due to a lack of self-perception, they are not able to visualize concrete options. They just have a feeling that there is something else different from that hostile world that has made them prisoners of their own bodies. Undoubtedly, that points out towards an important awakening, but it does not consolidate the underlying feminist project of the novels:

I was sure in that moment, as I had never been before: I didn't need to plant any other thoughts into my heart, into my head. I looked at the sky, that orange dot that was rising, a passing cloud, the air, the memory of your sad eyes. I turned. (Iglesias, 2013: p. 212)

This is not the story of a whore on the rise that will sooner or later end up dead or flailing about in the same drainage that engendered her. In fact, this story starts when it ends. And stories never end, they are full of gaps, false clues, contradictions. (Villafuerte, 2011: p. 400)

Consequently, it can be argued that the novels do not present a real emancipation strategy, as they do not materialize the intention of subverting the writing of whores as a means towards the release of the woman-body stereotype.

\section{Conclusions}

In the Mexican narrative written by women born after 1970, a strong interest to subvert the traditional submission and passive roles assigned to women is observed, through the representation of female characters that are highly eroticized and that practice their sexuality at will.

However, in texts like Por el ladosalvaje and Señorita Vodka, the hypersexualization of the characters does not really lead them towards emancipation or towards the release of their woman-body condition as, in the end, they restore a sentimental and affective dependency towards their former couple or specific male-oriented values that invoke the world they wish to escape from.

In such sense, the texts here studied end up reinforcing the subjugation and domination roles, while the main characters even assume the sexual, psychologic and physical violence they suffer from, to the extent of also perpetrating it 
themselves.

Hence, symbolic violence becomes evident in these texts as, through an alleged emancipatory and libertarian discourse, naturalization of violence against women is reproduced, along with the notion of the female body for the enjoyment and service of others. Although it is true that there is an underlying emerging feminist project in such claim, in the end it becomes diluted, as it is just vaguely mentioned and the possibility for an authentic release that goes beyond the sexualized body is merely guessed. This is why the novels cannot be part of the post porn proposal, as they do not present a clear stand on the full and total realization of sexuality as a means towards democratization between genders.

Thereby, the novels studied in this paper are seeds that pretend to contribute to women emancipation in Mexico, even when, as Lía mentions, that search process will always have contradictions.

\section{References}

[1] Fernández Perea, M. (Coord.) (2008) La literatura mexicana del siglo XX [Mexican Literature of the 20th Century]. Fondode Cultura Económica/CONACULTA/ Universidad Veracruzana, Mexico.

[2] Gutiérrez, L.G. (2012) Literatura mexicana del siglo XX. Estudios y apuntes [Mexican literature of the 20th Century.Studies and Notes]. Autonomous University of the State of Juan Pablos Editor, Mexico.

[3] Arrom, J.J. (1963) Esquema generacional de las letras hispanoamericanas. Ensayo de un método [Generational scheme of Hispanic American literatura: a method's essay]. Instituto Caro y Cuervo [Caro y Cuervo Institute], Bogota.

[4] Salinas, P. (1970) Literaturaespañolasiglo XX [Spanish literature of the 20th Century]. Alianza Editorial, Madrid.

[5] Padilla, I. (2007) Si hace crack es boom [If It Makes "Crack" It Is "Boom”]. Umbriel, Barcelona.

[6] Maldonado, T. (2008) Grandes hits. Nueva generación de narradores mexicanos, Vol. 1 [Greatest Hits. The new generation of Mexican writers, Vol. 1]. Almadía, Oaxaca de Juárez.

[7] Chimal, A. (2012) La generación Z y otros ensayos [Generation Z and other essays]. CONACULTA, Mexico.

[8] Valenzuela Navarrete, G. (2014) Nuevos narradores mexicanos: ¿qué y cómo cuenta la generación de los setenta? [New Mexican Writers: What Does the Seventies Generation Tell, and How?] Artes e Historia México. http://www.arts-history.mx/

[9] Hind, E. (2003) Entrevistas con quince autoras mexicanas [Interviews with fifteen Mexican writers]. Iberoamericana/Vervuert, Madrid.

[10] Hind, E. (2010) Feminism and the Mexican Woman Intellectual from Sor Juana to Poniatowska. Palgrave Macmillan, New York. https://doi.org/10.1057/9780230113497

[11] Alvarado Ruiz, R. (2008) Zarcalimita y la Geografía Literaria [Zarcalimita and the Literary Geography]. Espéculo, XII, 37, 1-7.

http://pendientedemigracion.ucm.es/info/especulo/numero37/zarcala.html 
[12] Sáenz Valadez, A. (2011) Una Mirada a la Racionalidad Patriarcal en México en los años Cincuenta y Sesenta del Siglo XX. Estudio de la moral en «Los años falsos» de Josefina Vicens [An Insight towards the Patriarchal Rationality in the Fifties and Sixties of the 20th Century. A Study on the Morale of «The False Years» of Josefina Vicens]. UMSNH/PIFI/Plaza and Valdés, Morelia.

[13] Domenella, A.R. (2001) Territorio de Leonas. Cartografía de Narradoras Mexicanas en los Noventa [Territory of Lionesses, Cartography of Mexican Female Writers in the Nineties]. UAM/Casa Juan Pablos, Mexico City.

[14] Castañeda, J.C. (2008) Los Noventa: Los años Intempestivos [The Nineties: the Untimely Years]. In: Fernández Perea, M., et al., Eds., La Literatura Mexicana del Siglo XX [Mexican literatura of the 20th Century], Fondo de Cultura Económica /CONACULTA/Universidad Veracruzana, Veracruz, 457-491.

[15] Pallais, M.L. (2004) Califica Carlos Fuentes a Volpi "Como un Archipiélago" [Carlos Fuentes Describes Volpi "as an Archipelago"]. http://www.cronica.com.mx/notas/2004/155320.html

[16] Bourdieu, P. (1972) Esquisse d'une Théorie de la Pratique. Droz, Paris. https://doi.org/10.3917/droz.boaurd.1972.01

[17] Barbier, R. (2014) La Violence Symbolique. Barbier-rd.nom.fr, 1-3. http://www.barbier-rd.nom.fr/violencesymbolique.html

[18] Hernández Morales, C.J. (2014) El Lugar de la Violencia Simbólica en la Teoría de Pierre Bourdieu [The place of symbolic violence in Pierre Bourdieu's theory]. Redes de Profesorado. http://redes.cepcordoba.org/file.php/26/ViolenciaSimbolicaBourdieu.pdf

[19] Tabuenca Córdoba, M.S. (2004) Violencia, Género y Literatura. Apuntes Para Reflexionar [Violence, Gender, and Literature. Notes to Reflect on]. In: Fernández de Juan, T., et al., Eds., Violencia contra la mujer en México [Violence against women in Mexico], Comisión Nacional de los Derechos Humanos [National Commission for Human Rights], Mexico City, 195-220.

[20] de la Concha, Á. (2012) El Sustrato Cultural de la Violencia de Género. Literatura, Arte, Cine y Videojuegos [The Cultural Substrate of Gender Violence. Literature, Arts, Films and Videogames]. Síntesis, Madrid.

[21] Walter, N. (2010) Muñecas Vivientes. El Regreso del Sexismo [Living Dolls. The Return of Sexism]. Rilla, M.Á., Trans., Turner Publicaciones, Madrid.

[22] Oliver, E. and Valls, R. (2004) Violencia de Género. Investigaciones Sobre Quiénes, por qué y cómo Superarlo [Gender Violence: Research over Who, Why, and How to Overcome It]. El Roure Editorial, Barcelona.

[23] Villafuerte, N. (2011) Por el Lado Salvaje. Ediciones B, Mexico City.

[24] Iglesias, S. (2013) Señorita Vodka. Tusquets, Mexico City.

[25] Bal, M. (2006) Teoría de la Narrativa (una Introducción a la Narratología) [Theory of Narrative (An Introduction to Narratology)]. Franco, J., Trans., 7th Edition, Cátedra, Madrid.

[26] Valle Ferrer, D. (2011) Espacios de Libertad: Mujeres, Violencia Doméstica y Resistencia [Spaces of Freedom: Women, Violence, and Resistance]. Espacio Editorial, Buenos Aires.

[27] Espinar Ruiz, E. and Mateo Pérez, M.Á. (2007) Violencia de Género: Reflexiones Conceptuales,Derivaciones Prácticas [Gender Violence: Conceptual Considerations, Practical Derivations]. University of Alicante, San Vicente del Raspeig.

[28] de Roca, C. (2013) Niñas Objeto [Object Girls]. Cimacnoticias. 
http://www.cimacnoticias.com.mx/node/64337

[29] Echavarren, R., Hamed A. and Lissardi, E. (2009) Porno y Postporno [Porn and Post Porn]. HUM, Montevideo.

[30] Bourcier, M.H. (2011) Queer Zones, Politiques des Identités Sexuelles et des Savoirs. Éditions Amsterdam, Paris.

[31] Lust, É. (2014) ¿Y por qué tanto lío con Érika Lust? http://erikalust.com/es/

[32] Torres, D. (2014) Pornoterrorismo. http://pornoterrorismo.com/

[33] Valencia, S. (2014) Teoría Transfeminista Para el Análisis de la Violencia Machista y la Reconstrucción No-Violenta del Tejido Social en el México Contemporáneo [Transfeminist Theory for the Analysis of Chauvinist Violence and the Non-Violent Reconstruction of the Social Fabric in Contemporary Mexico]. Universitas Humanísticas, 78, 66-88.

$\underline{\text { http://revistas.javeriana.edu.co/index.php/univhumanistica/article/view/6392 }}$

\section{Scientific Research Publishing}

Submit or recommend next manuscript to SCIRP and we will provide best service for you:

Accepting pre-submission inquiries through Email, Facebook, LinkedIn, Twitter, etc. A wide selection of journals (inclusive of 9 subjects, more than 200 journals)

Providing 24-hour high-quality service

User-friendly online submission system

Fair and swift peer-review system

Efficient typesetting and proofreading procedure

Display of the result of downloads and visits, as well as the number of cited articles

Maximum dissemination of your research work

Submit your manuscript at: http://papersubmission.scirp.org/

Or contact jss@scirp.org 